\title{
Concentrations of 5-ASA and Ac-5-ASA in human ileocolonic biopsy homogenates after oral 5-ASA preparations
}

\author{
M De Vos, H Verdievel, R Schoonjans, M Praet, M Bogaert, F Barbier
}

\begin{abstract}
Intramucosal 5-aminosalicyclic acid (5-ASA) and acetylated 5-ASA (Ac-5-ASA) concentrations were determined in ileocolonic biopsy specimens from 61 patients with irritable bowel syndrome treated for one week with near equimolar doses of different slow release preparations of 5-ASA (Claversal, Asacol, or Pentasa) or azo-bound drugs (Salazopyrin, Dipentum). The transit time in these patients was accelerated by a laxative, metoclopramide, and colonic lavage. The presence of 5-ASA in the mucosa was confirmed by autofluorescence. The highest concentrations of 5-ASA were obtained after Asacol (mean (SEM), $298 \cdot 5(37 \cdot 3) \mathrm{ng} / \mathrm{mg}$ wet wt), followed by Claversal $500 \mathrm{mg}(108.8(11.7) \mathrm{ng} / \mathrm{mg}$ wet wt) and Pentasa $(25 \cdot 7(2 \cdot 2) \mathrm{ng} / \mathrm{mg}$ wet wt). Very low concentrations only were observed after Claversal $250 \mathrm{mg}(0.3(0.03) \mathrm{ng} / \mathrm{mg}$ wet wt), Salazopyrine $(1.2(0.1) \mathrm{ng} / \mathrm{mg}$ wet wt), and Dipentum (11.0 (3.2) ng/mg wet wt). The results for Ac-5-ASA were similar but the concentrations were generally lower. Serum concentration-time curves over eight hours were obtained from $\mathbf{3 4}$ healthy volunteers after a single oral dose of 400 to $500 \mathrm{mg}$ of the different drugs. For the slow release forms, an apparently inverse relationship was found between the area under the curve of the serum concentrations and the intramucosal concentrations, supporting the importance of the local availability of the drug. This inverse relationship was absent for the azo-bound drugs. Colonic washout induced mechanical removal of intraluminal 5-ASA with a secondary disturbance in absorption resulting in a rapid decline in the serum concentrations. However, only for Dipentum did this result in significantly lower 5-ASA mucosal concentrations. This is the first reported attempt to evaluate the mucosal availability of 5-ASA after different oral preparations. It shows that where transit time is accelerated higher mucosal concentrations occur after slow release preparations (except for Claversal 250 mg) than after azo-bound drugs. Additional studies are necessary to correlate these concentrations with clinical effects.

(Gut 1992; 33: 1338-1342)
\end{abstract}

5-Aminosalicylic acid (5-ASA) is the active moiety of sulphasalazine in inflammatory bowel disease. ${ }^{1-3}$ Because orally ingested, uncoated 5-ASA is almost completely absorbed in the stomach and the proximal small intestine, several methods have been used to delay and prevent this proximal absorption. In delayed release preparations (Asacol, Claversal), 5-ASA is coated with an acrylic based resin that dissolves at a $\mathrm{pH}$ greater than 6 . In a slow release preparation (Pentasa), 5-ASA is encapsulated in microspheres of ethyl-cellulose that gradually dissolve in the small intestine. Finally, in azobound drugs, bacterial azoreductases liberate two 5-ASA molecules (Dipentum) or split off 5-ASA from sulphapyridine (Salazopyrin).

The presumptive topical mode of action of 5-ASA ${ }^{56}$ suggests that it would be best to obtain a maximal concentration at the site of disease (the terminal ileum and colorectum). The urinary output of 5-ASA reflects the fraction that is absorbed in the small intestine, and that is not therefore available for the topical effect; the faecal concentrations represent the residual 5-ASA present in the bowel lumen. An 'ideal' 5-ASA containing preparation would give a low plasma concentration and urinary recovery but high faecal concentration. Faecal concentrations, however, provide only an indirect estimate of the drug available in the tissues. We have therefore developed a high performance liquid chromatography (HPLC) system to determine 5-ASA and its metabolite acetylated 5-ASA (Ac5-ASA) in biopsy specimen homogenates. We confirmed the presence of 5-ASA in the mucosa by autofluorescence and correlated these concentrations with serum concentration-time curves in healthy volunteers. At the same time we determined Ac-5-ASA concentrations to evaluate the mucosal acetylation.

Finally, we analysed the influence of oral colonic washout by comparing serum concentration-time curves in the steady state condition with those after the start of the lavage. We excluded this effect as sole explanation for the very low mucosal concentrations after Claversal $250 \mathrm{mg}$ tablets or azo-bound drugs by comparing rectosigmoidal concentrations in patients with and without lavage.

\section{Methods}

\section{SUBJECTS AND STUDY DESIGN}

\section{Patients}

Sixty one patients ( 27 men and 34 women) (mean age: $41 \cdot 8$ years; range: $17-74$ years) with irritable bowel syndrome were treated for one week with one of the following drugs:

Salazopyrin (Pharmacia AB, Uppsala, Sweden $), 500 \mathrm{mg} \times 6$ per day $(\mathrm{n}=22)$;

Pentasa (Gist Brocades, Delft, Netherlands) $250 \mathrm{mg} \times 6$ per day $(n=7)$; 
Dipentum (Pharmacia AB, Uppsala, Sweden) $250 \mathrm{mg} \times 6$ per day $(\mathrm{n}=6)$;

Claversal (Smith Kline Dauelsberg, Göttingen, Germany) $500 \mathrm{mg} \times 3$ per day $(\mathrm{n}=9)$, $250 \mathrm{mg} \times 6$ per day $(\mathrm{n}=8)$;

Asacol (Byk Cedona, Haarlem, Netherlands) $400 \mathrm{mg} \times 3$ per day $(\mathrm{n}=9)$.

These regimens provide near equal daily doses of 5-ASA. On days five to seven, $7.5 \mathrm{mg}$ sodiumpicosulfate (Laxoberon - Boehringer Ingelheim) were given to facilitate colonic washout. The last dose of 5-ASA was given at 6 am on day eight, after overnight fasting. No food or liquid was allowed until $9 \mathrm{am}$, when oral colonic lavage was started with an Endopeg solution (Vanden Bogaerde, Brussels, Belgium). Before each litre, $5 \mathrm{mg}$ metoclopramide were given orally. Most patients needed 31 (range 2-5 l) to obtain complete evacuation of the gut. Ileocolonoscopy was performed between 2 and $3 \mathrm{pm}$ with an Olympus CF 10 endoscope under sedation with $5 \mathrm{mg}$ midazolam and $50 \mathrm{mg}$ pethidine. Two adjacent biopsy specimens were taken from the terminal ileum, the ileocaecal valve, and from eight different sites in the colon. The specimens were weighed immediately, frozen in liquid nitrogen, and stored at $-80^{\circ} \mathrm{C}$. The interval between taking and freezing the biopsy specimens was less than 30 minutes. In eight patients taking slow release preparations, the influence of colonic washout on the serum concentrationtime curve was analysed by comparing the curves on days seven and eight. The influence of lavage was evaluated by comparing the corresponding concentrations on both days.

In 13 patients, the influence of the washout on the mucosal Ac-5-ASA and 5-ASA concentrations was analysed by determining the concen- trations in rectal and sigmoid biopsy specimens from patients who had not undergone lavage. A similar time interval was respected between the intake of the last dose of drug and the endoscopy. Its influence was analysed for the preparations with very low mucosal concentrations (Dipentum $(n=6)$, Salazopyrin $(n=4)$ Claversal $250 \mathrm{mg}$ tablets $(\mathrm{n}=3)$ ). Six biopsies specimens were taken from every patient.

Finally, in a few patients treated with Asacol $(\mathrm{n}=2)$, Claversal $500 \mathrm{mg}$ tablets $(\mathrm{n}=2)$, Salazopyrin $(\mathrm{n}=2)$, and Claversal $250 \mathrm{mg}$ tablets $(n=1)$ additional biopsy specimens were taken from the ileum, sigmoid, and rectum. The specimens were frozen immediately in liquid nitrogen and subjected to autofluorescence microscopy.

\section{Volunteers}

Serum concentration-time curves over eight hours were obtained from 34 healthy volunteers after a single oral intake of $500 \mathrm{mg}$ Pentasa $(\mathrm{n}=5)$, two Claversal $250 \mathrm{mg}$ tablets $(\mathrm{n}=5)$, one Claversal $500 \mathrm{mg}$ tablet $(\mathrm{n}=8), 1000 \mathrm{mg}$ Salazopyrin $(n=5), 500 \mathrm{mg}$ Dipentum $(n=5)$, or $400 \mathrm{mg}$ Asacol $(\mathrm{n}=6)$.

\section{ASSAY METHODS}

HPLC

HPLC was used to determine 5-ASA and Ac-5-ASA in serum and in biopsy specimen homogenates as previously described.? The detection limit for both 5-ASA and Ac-5-ASA in biopsy homogenates was approximately $1 \mathrm{ng}$; the results were expressed as $\mathrm{ng} / \mathrm{mg}$ wet wt. The detection limit for serum was $2 \mathrm{ng} / \mathrm{ml}$.

TABLE I Steady state concentrations of 5-aminosalicylic acid (5-ASA) in biopsy specimen homogenates (ng/mg wet wt). (Values are mean $(S E M)$ )

\begin{tabular}{|c|c|c|c|c|c|c|c|c|c|c|c|}
\hline Product & $I L E$ & $I C V$ & $C A E$ & $A S C$ & $H E P$ & $T R A$ & $S P L$ & $D E S$ & $S I G$ & $R E C$ & Total \\
\hline $\begin{array}{c}\text { Salazopyrin } \\
(\mathbf{n}=22)\end{array}$ & $\begin{array}{c}1.8 \\
(0.5)\end{array}$ & $\begin{array}{c}1 \cdot 0 \\
(0 \cdot 3)\end{array}$ & $\begin{array}{c}1.2 \\
(0.6)\end{array}$ & $\begin{array}{c}1.5 \\
(0.6)\end{array}$ & $\begin{array}{c}0 \cdot 8 \\
(0 \cdot 2)\end{array}$ & $\begin{array}{c}1 \cdot 2 \\
(0 \cdot 4)\end{array}$ & $\begin{array}{c}1 \cdot 2 \\
(0 \cdot 3)\end{array}$ & $\begin{array}{c}1 \cdot 1 \\
(0 \cdot 3)\end{array}$ & $\begin{array}{c}0.9 \\
(0 \cdot 2)\end{array}$ & $\begin{array}{c}1 \cdot 4 \\
(0 \cdot 4)\end{array}$ & $\begin{array}{c}1 \cdot 2 \\
(0 \cdot 1)\end{array}$ \\
\hline $\begin{array}{c}\text { Pentasa } \\
\quad(n=7)\end{array}$ & $\begin{array}{l}33 \cdot 6 \\
(7 \cdot 8)\end{array}$ & $\begin{array}{l}26 \cdot 7 \\
(4 \cdot 0)\end{array}$ & $\begin{array}{l}25 \cdot 7 \\
(5 \cdot 1)\end{array}$ & $\begin{array}{l}29 \cdot 4 \\
(6 \cdot 7)\end{array}$ & $\begin{array}{l}19 \cdot 5 \\
(4 \cdot 6)\end{array}$ & $\begin{array}{c}33 \cdot 2 \\
(12 \cdot 5)\end{array}$ & $\begin{array}{l}27 \cdot 5 \\
(8 \cdot 0)\end{array}$ & $\begin{array}{l}17 \cdot 8 \\
(3 \cdot 5)\end{array}$ & $\begin{array}{l}29 \cdot 8 \\
(7 \cdot 8)\end{array}$ & $\begin{array}{l}14 \cdot 2 \\
(2 \cdot 3)\end{array}$ & $\begin{array}{l}25 \cdot 7 \\
(2 \cdot 2)\end{array}$ \\
\hline $\begin{array}{c}\text { Dipentum } \\
(n=6)\end{array}$ & $\begin{array}{c}9 \cdot 1 \\
(5 \cdot 7)\end{array}$ & $\begin{array}{c}6 \cdot 6 \\
(4 \cdot 2)\end{array}$ & $\begin{array}{c}4.4 \\
(2.9)\end{array}$ & $\begin{array}{c}27 \cdot 2 \\
(19 \cdot 0)\end{array}$ & $\begin{array}{c}17 \cdot 6 \\
(16 \cdot 7)\end{array}$ & $\begin{array}{l}10 \cdot 2 \\
(9 \cdot 7)\end{array}$ & $\begin{array}{l}13.9 \\
(9.2)\end{array}$ & $\begin{array}{c}8 \cdot 7 \\
(5 \cdot 7)\end{array}$ & $\begin{array}{c}7 \cdot 2 \\
(5 \cdot 0)\end{array}$ & $\begin{array}{c}4 \cdot 0 \\
(2 \cdot 5)\end{array}$ & $\begin{array}{l}11 \cdot 0 \\
(3 \cdot 2)\end{array}$ \\
\hline $\begin{array}{l}\text { Claversal } 500 \\
(n=9)\end{array}$ & $\begin{array}{l}173 \cdot 5 \\
(58 \cdot 1)\end{array}$ & $\begin{array}{l}110 \cdot 1 \\
(30 \cdot 0)\end{array}$ & $\begin{array}{c}96 \cdot 3 \\
(35 \cdot 3)\end{array}$ & $\begin{array}{l}117 \cdot 1 \\
(37 \cdot 8)\end{array}$ & $\begin{array}{l}82 \cdot 1 \\
(23 \cdot 6)\end{array}$ & $\begin{array}{l}125 \cdot 8 \\
(41 \cdot 4)\end{array}$ & $\begin{array}{l}111 \cdot 7 \\
(33 \cdot 4)\end{array}$ & $\begin{array}{l}105 \cdot 0 \\
(39 \cdot 3)\end{array}$ & $\begin{array}{c}81 \cdot 5 \\
(28 \cdot 4)\end{array}$ & $\begin{array}{c}91 \cdot 5 \\
(31 \cdot 1)\end{array}$ & $\begin{array}{l}108 \cdot 8 \\
(11 \cdot 7)\end{array}$ \\
\hline $\begin{array}{l}\text { Claversal } 250 \\
(n=8)\end{array}$ & $\begin{array}{c}0.5 \\
(0.1)\end{array}$ & $\begin{array}{c}0 \cdot 4 \\
(0 \cdot 2)\end{array}$ & $\begin{array}{c}0.2 \\
(0.06)\end{array}$ & $\begin{array}{c}0.2 \\
(0.09)\end{array}$ & $\begin{array}{c}0.2 \\
(0.06)\end{array}$ & $\begin{array}{c}0.2 \\
(0.06)\end{array}$ & $\begin{array}{c}0.2 \\
(0.09)\end{array}$ & $\begin{array}{c}0.2 \\
(0 \cdot 06)\end{array}$ & $\begin{array}{c}0.2 \\
(0 \cdot 1)\end{array}$ & $\begin{array}{c}0 \cdot 2 \\
(0.08)\end{array}$ & $\begin{array}{c}0.3 \\
(0.03)\end{array}$ \\
\hline $\begin{array}{l}\text { Asacol } \\
\qquad(n=9)\end{array}$ & $\begin{array}{c}477 \cdot 3 \\
(188 \cdot 6)\end{array}$ & $\begin{array}{c}576 \cdot 6 \\
(166 \cdot 8)\end{array}$ & $\begin{array}{c}525.9 \\
(162.5)\end{array}$ & $\begin{array}{c}370 \cdot 0 \\
(125 \cdot 6)\end{array}$ & $\begin{array}{l}237 \cdot 7 \\
(56 \cdot 1)\end{array}$ & $\begin{array}{c}320 \cdot 1 \\
(130 \cdot 0)\end{array}$ & $\begin{array}{c}300 \cdot 0 \\
(125 \cdot 0)\end{array}$ & $\begin{array}{l}123 \cdot 2 \\
(31 \cdot 4)\end{array}$ & $\begin{array}{l}118 \cdot 0 \\
(34 \cdot 0)\end{array}$ & $\begin{array}{l}108 \cdot 5 \\
(37 \cdot 2)\end{array}$ & $\begin{array}{l}298 \cdot 5 \\
(37 \cdot 3)\end{array}$ \\
\hline
\end{tabular}

ILE = terminal ileum; ICV = ileocaecal valve; $\mathrm{CAE}=$ caecum; $\mathrm{ASC}=$ ascending colon; $\mathrm{HEP}=$ hepatic flexure; $\mathrm{TRA}=$ transverse colon; $\mathrm{SPL}=$ splenic flexure; $\mathrm{DES}=$ descending colon; $\mathrm{SIG}=$ sigmoid colon; $\mathrm{R}=$ rectum .

TABLE II Steady state concentrations of Ac-5-ASA in biopsy specimen homogenates (ng/mg wet wt). (Values are mean (SEM))

\begin{tabular}{|c|c|c|c|c|c|c|c|c|c|c|c|}
\hline Product & $I L E$ & $I C V$ & $C A E$ & $A S C$ & $H E P$ & $T R A$ & $S P L$ & $D E S$ & $S I G$ & $R E C$ & Total \\
\hline $\begin{array}{c}\text { Salazopyrin } \\
(n=22)\end{array}$ & $\begin{array}{c}3.0 \\
(0.6)\end{array}$ & $\begin{array}{c}1.4 \\
(0 \cdot 3)\end{array}$ & $\begin{array}{c}2 \cdot 0 \\
(0 \cdot 8)\end{array}$ & $\begin{array}{c}2 \cdot 1 \\
(0 \cdot 5)\end{array}$ & $\begin{array}{c}1 \cdot 7 \\
(0 \cdot 4)\end{array}$ & $\begin{array}{c}2 \cdot 4 \\
(0 \cdot 4)\end{array}$ & $\begin{array}{l}2 \cdot 6 \\
(0 \cdot 5)\end{array}$ & $\begin{array}{c}2 \cdot 7 \\
(0 \cdot 5)\end{array}$ & $\begin{array}{c}2 \cdot 4 \\
(0.5)\end{array}$ & $\begin{array}{c}2 \cdot 9 \\
(0 \cdot 7)\end{array}$ & $\begin{array}{c}2 \cdot 3 \\
(0 \cdot 2)\end{array}$ \\
\hline Pentasa & $\begin{array}{l}12 \cdot 3 \\
(0.8)\end{array}$ & 12.0 & $19 \cdot 1$ & $\begin{array}{r}24.9 \\
(5.3)\end{array}$ & $24 \cdot 2$ & $26 \cdot 2$ & $20 \cdot 4$ & 23.9 & $25 \cdot 5$ & $17 \cdot 4$ & $20 \cdot 6$ \\
\hline Dipentum & $\begin{array}{l}1.5 \\
(0.7)\end{array}$ & $\begin{array}{l}1.5 \\
0.7\end{array}$ & $\begin{array}{l}1.6 \\
0.7\end{array}$ & $\begin{array}{c}5 \cdot 2 \\
(3 \cdot 0)\end{array}$ & $\begin{array}{c}4 \cdot 7 \\
4 \cdot 0)\end{array}$ & $\begin{array}{c}5.4 \\
(4 \cdot 4)\end{array}$ & $\begin{array}{l}7 \cdot 2 \\
(4 \cdot 3)\end{array}$ & $\begin{array}{c}6.9 \\
(3 \cdot 8)\end{array}$ & $\begin{array}{c}5.4 \\
(2.9)\end{array}$ & 3.6 & $\begin{array}{l}4.4 \\
(1.0)\end{array}$ \\
\hline $\begin{array}{c}\text { Claversal } 500 \\
(n=9)\end{array}$ & $\begin{array}{l}25 \cdot 3 \\
(5 \cdot 3)\end{array}$ & $\begin{array}{l}24 \cdot 1 \\
(5 \cdot 7)\end{array}$ & $\begin{array}{l}29 \cdot 4 \\
(4 \cdot 0)\end{array}$ & $\begin{array}{l}36 \cdot 6 \\
(5 \cdot 4)\end{array}$ & $\begin{array}{r}38 \cdot 6 \\
.(4 \cdot 9)\end{array}$ & $\begin{array}{l}42 \cdot 8 \\
(6.0)\end{array}$ & $\begin{array}{l}38.9 \\
(4.8)\end{array}$ & $\begin{array}{l}34 \cdot 0 \\
(4 \cdot 6)\end{array}$ & $\begin{array}{l}27 \cdot 4 \\
(3 \cdot 5)\end{array}$ & $\begin{array}{l}27.9 \\
(4.7)\end{array}$ & $\begin{array}{l}32 \cdot 4 \\
(1.6)\end{array}$ \\
\hline $\begin{array}{c}\text { Claversal } 250 \\
(n=8)\end{array}$ & $\begin{array}{l}0.8 \\
(0.3)\end{array}$ & $\begin{array}{c}0.6 \\
(0.2)\end{array}$ & $\begin{array}{l}0.7 \\
(0.2)\end{array}$ & 0.7 & $\begin{array}{c}0.6 \\
0.3)\end{array}$ & $\begin{array}{c}0.5 \\
(0.2)\end{array}$ & 0.4 & $\begin{array}{c}0.5 \\
(0.2)\end{array}$ & $\begin{array}{l}0.7 \\
0.3\end{array}$ & $\begin{array}{c}0.5 \\
0.2\end{array}$ & 0.6 \\
\hline $\begin{array}{c}\text { Asacol } \\
(n=9)\end{array}$ & $\begin{array}{l}19 \cdot 3 \\
(3 \cdot 8)\end{array}$ & $\begin{array}{l}26 \cdot 7 \\
(6 \cdot 1)\end{array}$ & $\begin{array}{l}40 \cdot 8 \\
(6 \cdot 8)\end{array}$ & $\begin{array}{l}37 \cdot 1 \\
(4 \cdot 8)\end{array}$ & $\begin{array}{l}36 \cdot 0 \\
(4 \cdot 3)\end{array}$ & $\begin{array}{l}30 \cdot 1 \\
(3 \cdot 8)\end{array}$ & $\begin{array}{l}32 \cdot 7 \\
(4 \cdot 1)\end{array}$ & $\begin{array}{l}37 \cdot 6 \\
(6 \cdot 3)\end{array}$ & $\begin{array}{l}35 \cdot 5 \\
(6 \cdot 4)\end{array}$ & $\begin{array}{l}28 \cdot 2 \\
(5 \cdot 5)\end{array}$ & $\begin{array}{l}32.8 \\
(1.7)\end{array}$ \\
\hline
\end{tabular}

See Table I for abbreviations. 

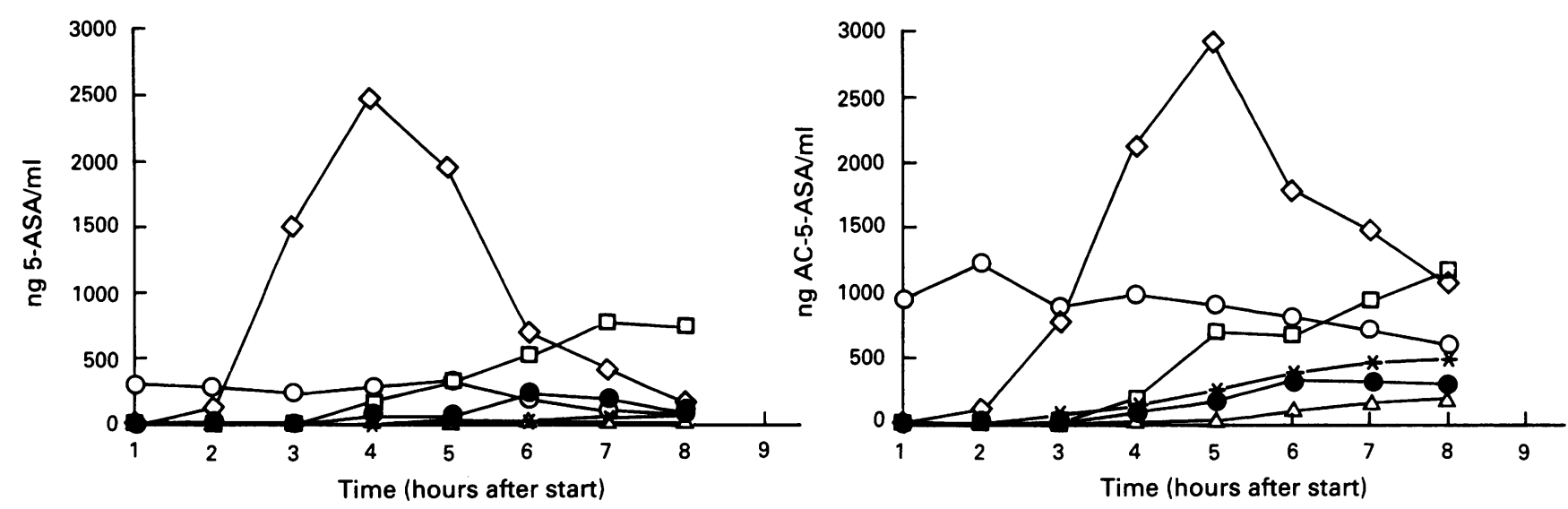

Asacol $\square$ Claversal 500 Pentasa * Dipentum $\Delta$ Salazopyrine $\diamond$ Claversal 250

Mean plasma concentrations of Ac-5-ASA and 5-ASA in healthy subjects after a single dose of different aminosalicylates (400-500 mg 5-ASA).

\section{Autofluorescence microscopy}

All samples were snap frozen in liquid nitrogen. Cryostat sections $(6 \mu)$ were cut within one hour (Frigocut model 2700 Reichert-Jung). The slides were air dried for 10 minutes at room temperature and then embedded in Entellan.

The slides were examined immediately with an Orthomat microscope equipped with a Leitz Wetzlar fluorescence light source for epifluorescence. Any delay was avoided since the lack of fixation and instability of 5-ASA at room temperature and daylight exposure promotes the fading of the autofluorescence. Since 5-ASA fluoresces when excited with a light source at $300-400 \mathrm{~nm}$, a heat filter (4 mm BG38 suppression filter), an excitation light filter (broad band incident light $2 \mathrm{~mm} \mathrm{UG1}$ ) and an emission light filter (suppression filter K 430) were applied.

\section{Results}

The mean (SEM) concentrations of 5-ASA and Ac-5-ASA in biopsy homogenates from different sites of the ileum and colorectum after drug intake are given in Tables I and II. The concentrations after the intake of Asacol, Claversal $500 \mathrm{mg}$ tablets, and Pentasa are significantly $(\mathrm{p}<0.05$; Mann-Whitney $\mathrm{U}$ test $)$ higher than after Claversal $250 \mathrm{mg}$ tablets, Dipentum, and Salazopyrin. The serum concentration-time curves of 5-ASA and Ac-5-ASA after a single dose of the different preparations in healthy volunteers are given in the Figure. $T_{\max }, C_{\max }$, and AUC are listed in Table III. For the slow release preparations an apparent inverse

TABLE III Area under the curve (AUC), time of maximal serum concentrations $\left(T_{\text {max }}\right)$, and maximal concentrations $\left(C_{\max }\right)$ of 5-ASA and Ac-5-ASA after oral intake of single dose $(400$ $500 \mathrm{mg}$ ) in healthy volunteers. (Values are mean (SEM))

\begin{tabular}{|c|c|c|c|c|c|c|}
\hline \multirow[b]{2}{*}{ Product } & \multicolumn{2}{|c|}{$A U C(n g \times h / m l)$} & \multicolumn{2}{|c|}{$T_{\max }(h)$} & \multicolumn{2}{|l|}{$C_{\max }(n g / m l)$} \\
\hline & 5-ASA & $A c-5-A S A$ & 5-ASA & $A c-5-A S A$ & 5-ASA & $A c-5-A S A$ \\
\hline $\begin{array}{l}\text { Salazopyrin }(n=5) \\
\text { Pentasa }(n=5) \\
\text { Dipentum }(n=5) \\
\text { Claversal } 500(n=8) \\
\text { Claversal } 250(n=5) \\
\text { Asacol }(n=6)\end{array}$ & $\begin{array}{c}63(31) \\
1842(488) \\
203(67) \\
2133(786) \\
7270(2850) \\
496(265)\end{array}$ & $\begin{array}{l}382(166) \\
6805(1144) \\
1550(572) \\
2989(900) \\
9699(2248) \\
1074(483)\end{array}$ & $\begin{array}{l}7 \\
5 \\
8 \\
7 \\
4 \\
6\end{array}$ & $\begin{array}{l}8 \\
4 \\
8 \\
8 \\
5 \\
6\end{array}$ & $\begin{array}{c}25(14) \\
304(123) \\
76(23) \\
790(590) \\
2484(1271) \\
208(145)\end{array}$ & $\begin{array}{r}190(54) \\
987(177) \\
504(107) \\
1160(454) \\
2910(754) \\
338(171)\end{array}$ \\
\hline
\end{tabular}

relationship is found between the AUC (Table III) and the mucosal concentrations (Table I). This inverse relationship is absent for the azobound drugs. Colonic washout reduces rapidly and significantly the serum concentrations of 5-ASA and Ac-5-ASA as seen in Table IV. The effect of the colonic washout on the mucosal 5-ASA concentrations after the intake of Salazopyrin and Claversal $250 \mathrm{mg}$ tablets was only moderate. In contrast, a much higher effect was found for Dipentum (Table V).

\section{Autofluorescence}

Biopsy specimen homogenates from patients taking Claversal $250 \mathrm{mg}$ tablets and Salazopyrin show only a faint fluorescence. In contrast, patients on Claversal $500 \mathrm{mg}$ tablets and Asacol show considerable staining of the cytoplasm of the covering enterocytes and the presence of fluorescence in single cells in the lamina propria with irregular cytoplasmatic extensions. These cells are probably macrophages.

\section{Discussion}

In steady state conditions, 5-ASA and Ac-5-ASA concentrations in biopsy homogenates depend on the galenic formulation and the chemical structure of the oral preparations tested. Significantly higher concentrations are found after most slow release preparations (Asacol, Pentasa, and Claversal $500 \mathrm{mg}$ tablets) than after azo-bound preparations (Dipentum and Salazopyrin). A large intra- and interindividual variation is found, as reported in all previous pharmacokinetic studies of the different 5-ASA formulations.

The apparent inverse relationship between the AUC and the intramucosal concentrations of the slow release drugs supports the hypothesis that the local availability of the drug is the major determinant of the mucosal concentrations. After the intake of azo-bound drugs, the mucosal concentrations are very low despite a low systemic absorption. This suggests impaired delivery of 5-ASA, also found in the study of Rijk et $a l^{8}$ in which the influence of the acceleration of 
TABLE IV Influence of colonic washout on steady state serum concentrations $(\mathrm{ng} / \mathrm{ml})$ of $A \mathrm{c}-5-A S A$ and $5-A S A$ four to six hours after the intake of the last dose (corresponding with one to three hours after start of washout) $(n=8$ patients on release modified preparations)

\begin{tabular}{|c|c|c|c|c|}
\hline \multirow[b]{3}{*}{ Interval $(h)$} & \multicolumn{4}{|c|}{ Serum concentrations (mean (SEM)) } \\
\hline & \multicolumn{2}{|l|}{ 5-ASA } & \multicolumn{2}{|l|}{$A c-5-A S A$} \\
\hline & Day 7 & Day 8 & Day 7 & Day 8 \\
\hline $\begin{array}{l}4(1) \\
5(2) \\
6(3)\end{array}$ & $\begin{array}{r}1219(664) \\
678(241) \\
916(368)\end{array}$ & $\begin{array}{l}154(79) \\
68(27)^{\star} \\
55(34)^{\star \star}\end{array}$ & $\begin{array}{l}1704(548) \\
1521(390) \\
1646(318)\end{array}$ & $\begin{array}{l}799(183) \\
491(91)^{\star} \\
348(109)^{\star \star}\end{array}$ \\
\hline
\end{tabular}

Wilcoxon rank test: ${ }^{\star} \mathrm{p}<0.05 ;{ }^{\star \star} \mathrm{p}<0.01$.

Day 7 represents steady state serum concentrations without washout; day 8 represents serum concentrations on the day of the washout.

the intestinal transit on urinary and faecal excretion of several 5-ASA preparations was analysed.

The diarrhoea induced by the colonic washout in our study provokes mechanical removal of the intraluminal 5-ASA. This results, even in steady state, in a rapid decline in serum concentrations. This reduction excludes early dissolution of the coat by Endopeg ( $\mathrm{pH} \mathrm{7 \cdot 4).} \mathrm{Although} \mathrm{this} \mathrm{wash-}$ out interferes with the pharmacokinetic profiles of the preparations, it is essential for the endoscopy and prevents the contamination of the biopsy specimens with the (Ac-)5-ASA from the stools. Furthermore, we can assume that this mechanical effect is similar for all preparations tested and does not greatly influence the conclusions about the results of the mucosal concentrations.

More difficult to study and quantify is the effect of the washout on the cleavage of the azobond. The acceleration of transit shortens the time available for the bacteria to split the azobond. The sterilisation of the gut by the washout can even prevent the cleavage. This effect seems more important for Dipentum than for Salazopyrin resulting in significantly higher mucosal concentrations in the rectum and sigmoid in patients who had not had previous washout. In contrast, mucosal concentrations after Salazopyrin remain low in both situations.

To minimise the effects of the washout we observed a delay of three hours between the intake of the last dose and the start of the washout to permit drug transit to the ileum, particularly because transit had already been accelerated in the previous three days by laxatives. This delay was based on our serum curves after single doses and on the studies of scintigraphic images of tablet disintegration showing a correlation with serum blood levels of 5-ASA. ${ }^{9}$ Our serum curves show the start of the release after one to three hours. Apparently no correlation is seen between the time of maximal release $\left(T_{\max }\right)$ and the mucosal concentrations suggest- ing that although the release pattern of the different drugs has certainly influenced our results, this influence should not be overestimated.

A concentration gradient through the colon is not observed except for a slight predominance in the ileum and right hemicolon after Asacol and Claversal $500 \mathrm{mg}$ corresponding to a large release of the drug.

To our knowledge, no previous studies of mucosal concentrations are available. Faecal concentrations are used as indirect estimates of the local concentrations. Comparative studies of faecal concentrations - after different aminosalicylates are few and provide contradictory results. Staerk Laursen $e t$ al ${ }^{10}$ estimated colonic concentrations by means of in vivo dialysis of faeces and found that in patients in steady state with inactive ulcerative colitis concentrations after olsalazine (Dipentum) and Asacol were almost double those seen with equimolar doses of Pentasa and salofalk (Claversal). In contrast, Rijk $e t a l^{8}$ evaluated the faecal excretions of healthy volunteers with accelerated transit time after a single dose. The trend in their results was similar to our findings: faecal excretion of 5-ASA was highest after Asacol, followed by Pentasa and Claversal, and lowest after Dipentum and Salazopyrin.

In our study, autofluorescence microscopy confirmed that 5-ASA penetrates the mucosa and does not only cover its surface. Moreover, this covering is reduced to a minimum by the colonic washout. The important differences in intramucosal concentrations after Claversal 250 and $550 \mathrm{mg}$ tablets were intriguing. Both drugs differ not only in terms of the dosage but also in the composition of the coating, giving rise to a different bioavailability.

Finally, we found significant Ac-5-ASA concentrations in the biopsy homogenates. In contrast with serum, the ratios of 5-ASA to Ac5-ASA are higher than 1 , reflecting the abundant supply of 5-ASA. This acetylation is an irreversible $^{11}$ and partially local ${ }^{12}$ process. However, the role of this probably therapeutically inactive metabolite ${ }^{13}$ remains unclear.

In conclusion, it can be said that during accelerated intestinal transit, slow release preparations, except for Claversal $250 \mathrm{mg}$ tablets, provide higher steady state mucosal concentrations than azo-bound drugs. These concentrations are inversely related to the AUC in serum supporting the role of the local availability of the drugs. Because of the proved clinical efficacy of Salazopyrin, despite very low mucosal concentrations, studies to correlate these concentrations with clinical benefit are necessary.
TABLE v Comparison of steady state Ac-5-ASA and 5-ASA concentrations ( $\mathrm{ng} / \mathrm{ml})$ in rectosigmoidal biopsy homogenates with and without colonic washout

\begin{tabular}{|c|c|c|c|c|c|c|}
\hline \multirow[b]{2}{*}{ Product } & \multicolumn{3}{|c|}{ Without washout } & \multicolumn{3}{|c|}{ With washout } \\
\hline & No & $5-A S A$ & $A c-5-A S A$ & No & $5-A S A$ & $A c-5-A S A$ \\
\hline $\begin{array}{l}\text { Dipentum } \\
\text { Salazo } \\
\text { Claversal } 250\end{array}$ & $\begin{array}{l}4 \\
5 \\
3\end{array}$ & $\begin{array}{r}19 \cdot 7(4 \cdot 3) \\
1.9(0 \cdot 5) \\
2 \cdot 5(1 \cdot 1)\end{array}$ & $\begin{array}{r}40 \cdot 2(6 \cdot 4) \\
6 \cdot 6(1 \cdot 1) \\
8 \cdot 4(3 \cdot 2)\end{array}$ & $\begin{array}{r}6 \\
22 \\
8\end{array}$ & $\begin{array}{l}5 \cdot 5(2 \cdot 7)^{\star \star \star} \\
1 \cdot 2(0 \cdot 1)^{\star} \\
0 \cdot 2(0.06)^{\star}\end{array}$ & $\begin{array}{l}4 \cdot 5(1 \cdot 7)^{\star \star \star} \\
2 \cdot 3(0 \cdot 2)^{\star \star \star \star} \\
0 \cdot 6(0 \cdot 2)^{\star \star}\end{array}$ \\
\hline
\end{tabular}

Mann-Whitney U test: ${ }^{\star} \mathrm{NS} ;{ }^{\star \star} \mathrm{p}<0.05 ;{ }^{\star \star \star} \mathrm{p}<0.01$

1 Azad Khan AK, Piris J, Truelove SC. An experiment to determine the active therapeutic moiety of sulphasalazine. Lancet 1977; ii: 892-5.

2 Van Hees PAM, Bakker JH, Van Tongeren JHM. Effect of sulphapyridine, 5-aminosalicylic acid and placebo in patients with idiopathic proctitis. A study to determine the patients with idiopathic proctitis. A study to determine the active therapeutic

3 Klotz U, Maier K, Fischer C, Heinkel K. Therapeutic efficacy of sulfasalazine and its metabolites in patients with ulcerative colitis and Crohn's disease. N Engl f Med 1980; 303: 1499 502 . 
4 Myers B, Evans DNW, Rhodes J, Evans BK, Hughes DR Lee MG, et al. Metabolism and urinary excretion of 5 -aminosalicylic acid in healthy volunteers when given intravenously or released for absorption at different sites in the gastrointestinal tract. Gut 1987; 28: 196-200.

5 Sutherland LR, Martin F, Greer S, Robinson M, Greenberger N, Saibil F, et al. 5-aminosalicylic acid enema in the treatment of distal ulcerative colitis, proctosigmoiditis and proctitis. Gastroenterology 1987; 92: 1894-8.

6 Campieri M, Gionchetti P, Belluzi A, Brignola C, Tabanelli GM, Miglioli M, et al. 5-amino-salicylic acid as enemas or uppositories in distal ulcerative colitis? f C lin Gastroenterol 1988; 10: 406-9.

7 De Vos M, Verdievel H, Schoonjans R, Beke R, De Weerdt GA, Barbier F. High-performance liquid chromatographic assay for the determination of 5 -aminosalicylic acid and assetyl-5-aminosalicylic acid concentrations in endoscopic acetyl-5-aminosalicylic acid concentrations in endoscopic
intestinal biopsy in humans. $\mathcal{F}$ Chromatogr 1991; 564: 296-

8 Rijk MCM, Van Hogezand RA, Van Schaik A, Van Tongeren HM. Disposition of 5-aminosalicylic acid-delivering drugs during accelerated intestinal transit in healthy volunteers.
Scand f Gastroenterol 1989; 24: 1179-85.

Healey JNC. Gastrointestinal transit and release of mesalazine tablets in patients with inflammatory bowel disease. Scand $\mathcal{F}$ Gastroenterol 1990; 25 (suppl 172): 47-51.

10 Staerk Laursen L, Stokholm M, Bukhave K, Rask-Madsen J, Lauritsen K. Disposition of 5 -aminosalicylic acid by olsalazine and three mesalazine preparations in patients with ulcerative colitis: comparison of intraluminal colonic concentrations, serum values and urinary excretion. Gut 1990 31: $1271-6$.

11 Meese $\mathrm{CO}$, Fischer $\mathrm{C}$, Klotz U. Is $\mathrm{N}$-acetylation of 5-aminosalicylic acid reversible in man? $\mathrm{Br} \mathcal{~ C l i n ~ P h a r m a c o l}$ 1984; 18: 612-5.

12 Allgayer $\mathrm{H}$, Ahnfelt NO, Kruis W, Klotz V, Frank Holmber K, Soderberg HNA, et al. Colonic N-acetylation of 5 -aminosalicylic acid in inflammatory bowel disease. Gastro5-aminosalicylic acid in in
enterology 1989; 97: 38-41.

13 Van Hogezand RA, Van Hees PAM, Van Gorp JPWM Van Lier HJJ, Bakker JH, Wesseling P, et al. Double blind comparison of 5-aminosalicylic acid and acetyl-5aminosalicylic acid suppositories in patients with idiopathic rectitis. Aliment Pharmacol Therap 1988; 2: 33-40. 